\title{
Recommendations for the urgent need to vaccinate school-aged and adolescent children against COVID-19 in the Asia-Pacific region
}

\author{
Jun Kobayashi ${ }^{1,2^{*}} \mathbb{D}$, Rie Takeuchi ${ }^{1,2}$, Fumiko Shibuya $^{1,2}$, Yuki Murata $^{3}$ and Kenzo Takahashi ${ }^{2,4}$
}

\begin{abstract}
We recommend urgent expansion of a vaccination program for adolescents and school-age children against SARSCoV-2 infection in the Western Pacific region. Since July 2021, SARS-CoV-2 infections in children have increased rapidly in this region. As infection rates rise due to the SARS-CoV-2 B.1.617.2 (Delta) variant, current preventive strategies such as mask wearing and social distancing have controlled its spread effectively. Prolonged school closure is currently being promoted to suppress virus spread among children. However, the negative impact of prolonged school closure is significant. Although vaccination of children under 12 is still controversial, preparations must be made now for their vaccination.
\end{abstract}

Keywords: COVID-19, Vaccine, Adolescent, School-aged children, Asia, Western Pacific region

\section{To the editor:}

Since July 2021, cases of SARS-CoV-2 infection have increased rapidly in the Western Pacific region. According to the World Health Organization (WHO), reported cases in this region have been lower than those elsewhere from 2020 to June 2021 [1]. The weekly number of cases reported on June 28 in the Western Pacific region was 128,103 , which was less than that in other regions: 991,946 cases in America, 544,679 in Europe, 612,933 in Southeast Asia, 245,930 in the Middle East, and 203,938 in Africa. This might be due not to the widespread use of vaccines but to cellular immunity, which might be acquired as an inborn characteristic by the inhabitants of the Asian region [2], or the thoroughness of hygienic behaviors such as hand washing and wearing of masks,

\footnotetext{
*Correspondence: junkobalao@gmail.com

${ }^{1}$ Department of Global Health, Graduate School of Health Sciences,

University of the Ryukyus, 207 Uehara, Nakagami-gun, Nishihara, Okinawa 903-0215, Japan

Full list of author information is available at the end of the article
}

and the success of measures to restrict human flow [3-5]. As of the end of June, vaccine coverage was $68 \%$ in Canada, $66 \%$ in the UK, $55 \%$ in Germany, and $54 \%$ in the USA, whereas only Singapore and China in the Western Pacific region were above $50 \%$. The rate was $26 \%$ in Japan, a high-income country, $7.1 \%$ in the Philippines, a lower middle-income country, and only $3.7 \%$ in Vietnam [6]. However, since the beginning of July 2021, the rate of weekly increase in cases has risen rapidly, ranging from 10 to $35 \%$ [1]. This is thought to be due in large part to the influx of SARS-CoV-2 B.1.617.2 (Delta). The Delta variant is reported to be an extremely highly contagious strain [7] and has become the predominant strain in much of the region as in other regions [8]. The rate of positivity of the Delta strain is reported to be about $67 \%$ in screening tests performed from 26 July to 1 August in Japan. Its numbers continue to rise and are replacing those of other variants. In Tokyo, in particular, the rate has been about $80 \%$, and the latest estimate is about $95 \%$ [9]. The effective reproduction number (Rt) was reported original author(s) and the source, provide a link to the Creative Commons licence, and indicate if changes were made. The images or other third party material in this article are included in the article's Creative Commons licence, unless indicated otherwise in a credit line to the material. If material is not included in the article's Creative Commons licence and your intended use is not permitted by statutory regulation or exceeds the permitted use, you will need to obtain permission directly from the copyright holder. To view a copy of this licence, visit http://creativecommons.org/licenses/by/4.0/. 
to exceed 1 in Tokyo in July and more than 2 in Okinawa at the beginning of August [10]. It can be inferred that this virus is easily spread despite the fact that nearly $100 \%$ of the people in Japan wear masks when going out.

\section{Increasing risk of infection among children}

The influx of the highly infectious Delta strain has put unvaccinated children in the region at greater risk of infection. On August 14, 2021, 1902 children were reportedly hospitalized in the United States. The Delta variant is spreading rapidly, mainly among the unvaccinated population, and hospitalizations have skyrocketed in recent weeks, and that of children under 12 years of age has surged to a record high [11]. Although children in this age group are not eligible for vaccination, they are still vulnerable to the Delta variants. A similar trend has been observed in Japan, with a sharp increase in infections occurring among children. Vaccination of children over 12 years of age has been approved; however, due to priority to adult vaccination, many children over the age of 12 in Japan are not being vaccinated, putting the entire population at risk, including adolescents [12]. So far, there is no indication that the spread of Delta strains has increased the rate of severe cases and sequelae. However, there are numerous reports of sequelae occurring after SARS-CoV-2 infection has been cured in all age groups including in children [13, 14]. It is estimated that the disease is spreading to children in other Western Pacific countries as well as the United States and Japan.

\section{Negative effects of prolonged school closures}

Once the increased risk of infection in children is recognized by policy makers and society, it is likely that there will be prolonged school closures in the Western Pacific region, the negative impact of which cannot be ignored [15]. Several studies reported that during the school closures, the time spent on physical activity decreased but sedentary time increased $[16,17]$, which may cause overweight in children [18]. In addition, school closure result in undernutrition in those children who depend on free meals in schools [19]. During the school closure period, i.e., the home-based learning period, children's sleeping time became longer than that before school closure, bedtime was later, and wake-up time was much later than that before school closure [17], indicating that children's life rhythm has been disturbed. Moreover, increased screen time due to home-based learning using internet materials was thought to have had some impact as well $[16,20]$, and even non-academic screen time also increased, which might affect children's sleep [17]. Furthermore, children's mental health has been affected, with increasing reports of behavioral problems, anxiety, depression, and stress [21,22].

\section{Development of a pediatric SARS-CoV-2 vaccine}

Development of a pediatric SARS-CoV-2 vaccine is still under way, and new related evidence is expected to emerge. As of August 20, 2021, evidence on mRNA and inactivated vaccines has been reported. As a potential pediatric COVID-19 vaccine, the mRNA-1273 SARS$\mathrm{CoV}-2$ vaccine has finished progression to a phase $2-3$ study in adolescents (13-17 years) and has shown efficacy in preventing SARS-CoV-2 infection [23]. As for mRNA vaccines, WHO, the US-CDC and the Mayo Clinic recommend BNT162b2 SARS-CoV-2 vaccine for adolescents [24, 25]. In terms of vaccine safety and acceptability, according to the US-CDC data on BNT162b2 SARS-CoV-2 vaccine, younger vaccine recipients were more prone to experience common side effects than older recipients, even though the data have only been roughly summarized [26]. As of August 27, 2021, a Nature News explainer article, one of the fastest and most reliable sources of information on COVID19 , reported that a variety of vaccines are under clinical trial for children over 12 years, and up to July 20, 2021, when the article was published, the vaccines appear to be safe at least for adolescents [27]. In addition, due to the emergence of variants of concern, the role of adolescents and young adults in the pandemic is coming into the limelight. In short, at least adolescents may contribute to transmission in families and communities that can be hampered by vaccines for adolescents [28]. As available evidence for other vaccines, a double-blind, randomized, controlled trial of an inactivated SARS-CoV-2 vaccine named CoronaVac conducted in 3-17 years has been completed without serious adverse effects being reported [29]. Thus, considering the trade-offs of risks (non-safety events) and benefits (protection from COVID-19), the benefits of this vaccine outweigh the risks.

The recent data suggest that the vaccine is safe, but there are limitations regarding ethnic bias and sample size, so we hope that this trial will continue. As of August 5, 2021, the American Academy of Pediatrics requested the US Food and Drug Administration to work continuously to authorize safe and effective COVID-19 vaccines for children under the age 12 as soon as possible [30].

\section{Urgent need for vaccination of children in the region}

Countries in the Asia-Pacific region should urgently implement vaccination against SARS-CoV-2 in adolescents to avoid prolonged school closures. We need to be prepared to start vaccinating school-age children under 12 years of age as soon as the safety of the vaccine is reported. We do not deny that the elderly are a priority group for vaccination, because their susceptibility to severe disease is indisputable. However, as of August 
2021, when many countries have achieved higher vaccination rates for the elderly, there is no reason to refrain from vaccinating children except for the fact that vaccine safety in children has not yet been confirmed. It is not as easy to prevent the spread of the virus among children in schools, as it is among adults because of the high infectivity of the Delta strain. It is much more difficult for school children to maintain social distance and to limit conversations at meals than it is for adults. In addition, children can be assumed to be spreaders of the virus and can potentially infect the elderly. In low- and middleincome countries, many poor people, from children to the elderly, live in small rooms. Furthermore, the efficacy of the vaccine in preventing both infection by the Delta strain and severe disease is reported to decline with time after vaccination. [31, 32].

With consideration of the severity of COVID-19 in children, more attention needs to be paid to children with underlying diseases. More than 2000 deaths have already been reported in Brazil and more than 1500 in India. The reported problems are due not only to access to medical services, but also to obesity and air pollution caused by poverty [33]. Agarwal et al. reported two severe cases of obese adolescent females [34]. In Cook islands, Nauru, Niue, Samoa, Tonga and Tuvalu, more than $40 \%$ of adolescent are reported to be obese, and obese children have become a major public health challenge in many of Pacific Island countries [35, 36]. In the Asia-Pacific region, 4 billion people are exposed to air pollution, and the air pollution in the Western Pacific region in the metropolitan areas of China, Korea, Japan, and Vietnam cannot be ignored [37]. A cohort study in the United States in 2020 showed that asthma may not be a risk factor for COVID-19, and in Chengdu, China, asthma in children was reported to be improving as a result of the lockdown there $[38,39]$. However, if the new Corona virus infections are controlled in the adult population and social activities increase, air pollution will once again become serious in the megacities of Asia. It will be necessary to observe whether this effect will impact the severity of the disease in children.

We believe that the creation of opportunities to inoculate both parents and children at the same time will be effective. In large companies, vaccinations are administered simultaneously in the workplace, but in smaller companies, it is necessary to get vaccinated individually. Flexible vacation time is not always recommended by companies for this reason, and in some cases, companies do not encourage their employees to leave the workplace for vaccinations. Vaccination hesitancy comes in stages, and not all people remain unvaccinated due to strong personal beliefs, but are influenced by the social mood [40]. Schools can be one important place to create a positive social mood to promote vaccination. The AsiaPacific region is one of the most advanced regions in the world in implementing Health Promoting Schools, so schools already have experience in creating a healthy and positive social environment [41]. We have shown that health behaviors associated with infectious diseases can be effectively disseminated from children to the community $[42,43]$. Schools will be able to inform not only children, but also their parents about COVID-19 control that includes vaccination promotion.

The WHO advisory group has already mentioned the future possibility of vaccinating children over the age of 12 because of the reported safety of the Pfizer vaccine. We expect that from now on, the safety of the Pfizer vaccine for children under 12 years and that of other companies' products will be reported [44]. Based on current experiences in each country of the region, it is quite possible that there will be delays in the approval process for vaccination by the governments and delays in the supply of vaccines to the various countries and in the development of supply systems by local governments and school-level vaccination sites. In particular, low- and middle-income countries have limited resources and will need adequate time to prepare. The problem of vaccine refusal is expected to increase as parents become more sensitive to safety issues, especially when it is their children who are being vaccinated. Therefore, from now on, central and local governments should request the education sector to convey appropriate information through conversations between the health and education sectors. At the school level, it will be necessary to use the experience gained to date to not only to reinforce transmission in schools, but also to strengthen the partnership with parents and communities in the fight against the new corona variants. In addition, some Pacific Island countries have not strengthened other public health approaches because of long-term border closure measures, and thus, it will be necessary to incorporate vaccination of school children into international assistance programs from now on as we continue to attempt to control the COVID-19 pandemic.

\section{Abbreviations \\ COVID-19: Coronavirus disease 2019; WHO: World Health Organization.}

\section{Acknowledgements}

Not applicable.

\section{Authors' contributions}

JK conceived the presented idea. JK, RT, FS, YM, and KT drafted the manuscript. $J \mathrm{~K}$ critically reviewed the manuscript. All authors read and approved the final manuscript

\section{Funding}

This research was funded by University of the Ryukyus Research Project toward Post-COVID society Grant and the EDU-Port Japan Project as "2021 
Research Project" under the Ministry of Education, Culture, Sports, Science and Technology, Japan.

\section{Availability of data and materials}

Not applicable. The manuscript does not contain any data.

\section{Declarations}

\section{Ethics approval and consent to participate}

Not applicable. The manuscript does not involve human participants or data.

\section{Consent for publication}

Not applicable. The manuscript does not contain any individual's personal data.

\section{Competing interests}

The authors declare that they have no competing interests.

\section{Author details}

${ }^{1}$ Department of Global Health, Graduate School of Health Sciences, University of the Ryukyus, 207 Uehara, Nakagami-gun, Nishihara, Okinawa 903-0215, Japan. ${ }^{2}$ Japanese Consortium of Global School Health Research, Okinawa, Japan. ${ }^{3}$ Department of General Pediatrics, Tokyo Metropolitan Children's Medical Center, Tokyo, Japan. ${ }^{4}$ Graduate School of Public Health, Teikyo University, Tokyo, Japan.

Received: 23 August 2021 Accepted: 7 September 2021 Published online: 16 September 2021

\section{References}

1. WHO. Coronavirus (COVID-19) Dashboard. 2021. https://covid19.who.int/. Accessed 20 Aug 2021.

2. Motozono C, Toyoda M, Zahradnik J, Saito A, Nasser H, Tan TS, et al. SARS-CoV-2 spike L452R variant evades cellular immunity and increases infectivity. Cell Host Microbe. 2021;29:1124-36.e11. https://doi.org/10. 1016/j.chom.2021.06.006.

3. Wang Y, Tian H, Zhang L, Zhang M, Guo D, Wu W, et al. Reduction of secondary transmission of SARS-CoV-2 in households by face mask use, disinfection and social distancing: a cohort study in Beijing, China. BMJ Glob Health. 2020;5:e002794. https://doi.org/10.1136/bmjgh-2020-002794.

4. Lyu W, Wehby GL. Community use of face masks and COVID-19: evidence from a natural experiment of state mandates in the US. Health Aff (Millwood). 2020;39:1419-25. https://doi.org/10.1377/hlthaff.2020.00818.

5. Leffler CT, Ing E, Lykins JD, Hogan MC, McKeown CA, Grzybowski A. Association of country-wide Coronavirus mortality with demographics, testing, lockdowns, and public wearing of masks. Am J Trop Med Hyg. 2020;103:2400-11. https://doi.org/10.4269/ajtmh.20-1015.

6. Coronavirus (COVID-19) Vaccinations. Our world in data. 2021. https:// ourworldindata.org/covid-vaccinations. Accessed 20 Aug 2021.

7. $L i B S$, Deng $A P, L i K B, H u Y, L i Z C$, Xiong QL, et al. Viral infection and transmission in a large, well-traced outbreak caused by the SARS-CoV-2 Delta variant. MedRxiv. 2021. https://doi.org/10.1101/2021.07.07.21260122.

8. WHO. COVID-19 weekly epidemiological update edition 53. 2021. https:// www.who.int/publications/m/item/weekly-epidemiological-update-oncovid-19---17-august-2021. Accessed 20 Aug 2021.

9. National Institute of Infectious Diseases. Recent infection status of the new coronavirus (11 August, 2021). 2021. https://www.niid.go.jp/niid/ ja/diseases/ka/corona-virus/2019-ncov/10572-covid19-ab47th.html. Accessed 20 Aug 2021. (in Japanese).

10. Okinawa Prefecture. Epidemiology, statistics and analysis committee materials. Figure 1. Changes in the number of positive cases and the effective reproduction number. 2021. https://www.pref.okinawa.jp/site/ chijiko/kohokoryu/0716.html. Accessed 20 Aug 2021. (in Japanese).

11. American Academy of Pediatrics. Children and COVID-19: state data report. 2021. https://www.aap.org/en/pages/2019-novel-coronaviruscovid-19-infections/children-and-covid-19-state-level-data-report. Accessed 20 Aug 2021.
12. Ministry of Health, Labour and Welfare. The number of children infected is increasing in Japan. 2021. https://corona.go.jp/proposal/pdf/chishiki_ 20210813.pdf. Accessed 20 Aug 2021. (in Japanese).

13. Marino A, Varisco T, Quattrocchi G, Amoroso A, Beltrami D, Venturiello S, et al. Children with Kawasaki disease or Kawasaki-like syndrome (MIS-C) PIMS) at the time of COVID-19: are they all the same? Case series and literature review. Reumatismo. 2021;73:48-53. https://doi.org/10.4081/ reumatismo.2021.1331.

14. Hageman JR. Long COVID-19 or post-acute sequelae of SARS-CoV-2 infection in children, adolescents, and young adults. Pediatr Ann. 2021;50:e232-3. https://doi.org/10.3928/19382359-20210519-02.

15. Kobayashi J, Takeuchi R, Toyama Y, Gregorio ER Jr, Kadriyan H, Estrada CAM, et al. Urgent need to strengthen school health in Asia and the Pacific Islands. Pediatr Int. 2021. https://doi.org/10.1111/ped.14921.

16. Velde GT, Lubrecht J, Arayess L, van Loo C, Hesselink M, Reijnders D, et al. Physical activity behaviour and screen time in Dutch children during the COVID-19 pandemic: pre-, during- and post-school closures. Pediatr Obes. 2021;16(9): e12779. https://doi.org/10.1111/ijpo.12779.

17. Lim MTC, Ramamurthy MB, Aishworiya R, Rajgor DD, Tran AP, Hiriyur P, et al. School closure during the coronavirus disease 2019 (COVID-19) pandemic —impact on children's sleep. Sleep Med. 2021;78:108-14. https:// doi.org/10.1016/j.sleep.2020.12.025.

18. Rundle AG, Park Y, Herbstman JB, Kinsey EW, Wang YC. COVID-19-related school closings and risk of weight gain among children. Obesity. 2020;28:1008-9. https://doi.org/10.1002/oby.22813.

19. Endocrinology TLD. Food for thought during school closures. Lancet Diabetes Endocrinol. 2020;8(11):869. https://doi.org/10.1016/S2213-8587(20) 30346-6.

20. Wang J, Li Y, Musch DC, Wei N, Qi X, Ding G, et al. Progression of myopia in school-aged children after COVID-19 home confinement. JAMA Ophthalmol. 2021;139:293-300. https://doi.org/10.1001/jamaophthalmol.

21. Liu Q, Zhou Y, Xie X, Xue Q, Zhu K, Wan Z, et al. The prevalence of behavioral problems among school-aged children in home quarantine during the COVID-19 pandemic in China. J Affect Disord. 2021;279:412-6. https://doi.org/10.1016/j.jad.2020.10.008.

22. Tang $\mathrm{S}$, Xiang M, Cheung T, Xiang YT. Mental health and its correlates among children and adolescents during COVID-19 school closure: the importance of parent-child discussion. J Affect Disord. 2021;279:353-60. https://doi.org/10.1016/j.jad.2020.10.016.

23. Ali K, Berman G, Zhou H, Deng W, Faughnan V, Coronado-Voges M, et al. Evaluation of mRNA-1273 SARS-CoV-2 vaccine in adolescents. N Engl J Med. 2021. https://doi.org/10.1056/NEJMoa2109522.

24. Center for Disease Control, USA. COVID-19 vaccines for children and teens. Atlanta, USA. https://www.cdc.gov/coronavirus/2019-ncov/vacci nes/recommendations/adolescents.html. Accessed 27 Aug 2021.

25. Mayo Clinic Staff. COVID-19 (coronavirus) in babies and children. Rochester, USA. https://www.mayoclinic.org/diseases-conditions/coronavirus/ in-depth/coronavirus-in-babies-and-children/art-20484405. Accessed 27 Aug 2021.

26. Centers for Disease Control. Local reactions, systemic reactions, adverse events, and serious adverse events: Pfizer-BioNTech COVID-19 vaccine. Atlanta, USA. https://www.cdc.gov/vaccines/covid-19/info-by-product/ pfizer/reactogenicity.html. Accessed 28 Aug 2021.

27. Ledford $\mathrm{H}$. Should children get COVID vaccines? What the science says. Nature. 2021;595(7869):638-9. https://doi.org/10.1038/ d41586-021-01898-9.

28. Guilamo-Ramos V, Benzekri A, Thimm-Kaiser M, Hidalgo A, Perlman DC. Reconsidering assumptions of adolescent and young adult severe acute respiratory syndrome Coronavirus 2 transmission dynamics. Clin Infect Dis. 2021;73(2):S146-63. https://doi.org/10.1093/cid/ciaa1348.

29. Han B, Song Y, Li C, Yang W, Ma Q, Jiang Z, et al. Safety, tolerability, and immunogenicity of an inactivated SARS-CoV-2 vaccine (CoronaVac) in healthy children and adolescents: a double-blind, randomised, controlled, phase 1/2 clinical trial. Lancet Infect Dis. 2021. https://doi.org/10. 1016/S1473-3099(21)00319-4

30. American Academy of Pediatrics. Letter to the Acting Commissioner, Food and Drug Administration. 2021. https://downloads.aap.org/DOFA/ AAP\%20Letter\%20to\%20FDA\%20on\%20Timeline\%20for\%20Authoriz ation\%20off20COVID-19\%20Vaccine\%20for\%20Children_08_05_21.pdf? fbclid=IwAR07F-N77QQpRfqCd6nMuNa4Z-mLkYCR_3eUMOnj70||15Nk3 yxLPLqmGbic. Accessed 20 Aug 2021. 
31. Rosenberg ES, Holtgrave DR, Dorabawila V, Conroy MB, Greene D, Lutterloh E, et al. New COVID-19 cases and hospitalizations among adults, by vaccination status-New York, May 3-July 25, 2021. CDC Morb Mortal Wkly Rep (MMWR). 2021;70(34):1150-5.

32. KFF. COVID-19 vaccine breakthrough cases: data from the states. https:// www.kff.org/policy-watch/covid-19-vaccine-breakthrough-cases-datafrom-the-states/. Accessed 27 Aug 2021.

33. New York Times. Poverty, disease, customs: why so many Indonesian children die of Covid-19. 2021. https://indianexpress.com/article/explained/ explained-why-so-many-indonesian-children-die-of-covid-19-7454614/. Accessed 27 Aug 2021.

34. Agarwal A, Karim F, Bowman AF, Antonett CR. Obesity as a risk factor for severe illness from COVID-19 in the pediatric population. Cureus. 2021;13(5): e14825. https://doi.org/10.7759/cureus.14825.

35. WHO. Overweight and obesity in the Western Pacific region. 2017. https://apps.who.int/iris/bitstream/handle/10665/255475/9789290618 133-eng.pdf?sequence=1\&isAllowed=y. Accessed 30 Aug 2021.

36. WHO. The first 20 years of the journey towards the vision of Healthy Islands in the Pacific, 2015. https://apps.who.int/iris/bitstream/handle/ 10665/208201/9789290617150_eng.pdf?sequence=1\&isAllowed=y. Accessed 30 Aug 2021.

37. Climate and Clean Air Coalition. Air pollution measures for Asia and the Pacific. 2021. https://www.ccacoalition.org/en/content/air-pollutionmeasures-asia-and-pacific. Accessed 30 Aug 2021.

38. Papadopoulos NG, Mathioudakis AG, Custovic A, Deschildre A, Phipatanakul W, Wong G, et al. Childhood asthma outcomes during the COVID-19 pandemic: findings from the PeARL multi-national cohort. Allergy. 2021;76(6):1765-75. https://doi.org/10.1111/all.14787.
39. Zhang L, Wang $X$, Huang $Y, A i T$, Liao H, Hu J, et al. Pediatric asthma situation in Chengdu, China, during the COVID-19 pandemic: an observational study. J Asthma Allergy. 2021;14:829-38. https://doi.org/10.2147/ JAA.S315695.

40. MacDonald NE, SAGE Working Group on Vaccine Hesitancy. Vaccine hesitancy: definition, scope and determinants. Vaccine. 2015;33(34):4161-4. https://doi.org/10.1016/j.vaccine.2015.04.036.

41. Estrada CAM, Gregorio ER Jr, Kanyasan K, Jeudyla H, Tomokawa S, Dumlao MC, et al. School health promotion in Southeast Asia by the Japan and partners. Pediatr Int. 2020;62(9):1029-38. https://doi.org/10.1111/ped. 14284.

42. Nonaka D, Kobayashi J, Jimba M, Vilaysouk B, Tsukamoto K, Kano S, et al. Malaria education from school to community in Oudomxay province. Lao PDR. 2008;57(1):76-82. https://doi.org/10.1016/j.parint.2007.09.005.

43. Ayi I, Nonaka D, Adjovu JK, Hanafusa S, Jimba M, Bosompem KM, et al School-based participatory health education for malaria control in Ghana: engaging children as health messengers. Malar J. 2010;9:98. https://doi.org/10.1186/1475-2875-9-98.

44. WHO. COVID-19 advice for the public: getting vaccinated. 2021. https:// www.who.int/emergencies/diseases/novel-coronavirus-2019/covid-19vaccines/advice. Accessed 30 Aug 2021.

\section{Publisher's Note}

Springer Nature remains neutral with regard to jurisdictional claims in published maps and institutional affiliations.
Ready to submit your research? Choose BMC and benefit from:

- fast, convenient online submission

- thorough peer review by experienced researchers in your field

- rapid publication on acceptance

- support for research data, including large and complex data types

- gold Open Access which fosters wider collaboration and increased citations

- maximum visibility for your research: over $100 \mathrm{M}$ website views per year

At BMC, research is always in progress.

Learn more biomedcentral.com/submissions 